\title{
ANALISIS IMPLEMENTASI PENDIDIKAN BERBASIS BUDAYA PADA LEMBAGA PENDIDIKAN NONFORMAL DI DAERAH ISTIMEWA YOGYAKARTA
}

\author{
Nur Djazifah ER, Mulyadi, dan S.Wisni Septiarti \\ Universitas Negeri Yogyakarta \\ Email: nurdjazifah@uny.ac.id
}

\begin{abstract}
Abstrak
Penelitian ini bertujuan untuk mendeskripsikan pentingnya analisis terhadap implementasi pendidikan berbasis budaya (Perda no 5 Tahun 2011) di Daerah Istimewa Yogyakarta khususnya pada Lembaga Kursus dan Pelatihan (LKP) sebagai layanan pendidikan masyarakat. Penelitian ini menggunakan pendekatan kualitatif. Hasil penelitian menunjukkan bahwa 1) sosialisasi pendidikan berbasis budaya dilakukan secara terstruktur dari tingkat propinsi hingga lembaga penyelenggara kursus melalui workshop, TOT, seminar, FGD; 2) Tingkat kesiapan LKP dalam menjalankan pendidikan berbasis budaya dari aspek isi, proses, sarana prasarana dan sumber daya manusia terlibat dalam layanan pendidikan masyarakat ini berbeda-beda. Terdapat 46 LKP di DIY dengan kualifikasi terakreditasi BANPNF ada sebagian yang belum sepenuhnya menerapkan pendidikan berbasis budaya;3) Beberapa kesulitan yang teridentifikasi kaitannya dengan implementasi Perda no 5 Tahun 2011 tentang pendidikan berbasis budaya ini meliputi kompleksitas permasalahan yang dihadapi LKP, kesulitan dalam mencari indikator pendidikan berbasis budaya berdasarkan nilai-nilai luhur budaya Yogyakarta sehingga tidak mudah untuk diintegrasikan ke dalam materi pembelajaran, waktu yang digunakan untuk menyusun kurikulum berbasis budaya ke dalam format-format yang baru sangat panjang dengan tim yang sering berganti-ganti sehingga terkesan melelahkan.
\end{abstract}

Kata kunci: pendidikan berbasis budaya

\section{IMPLEMENTATION ANALYSIS OF CULTURE-BASED EDUCATION IN NON-FORMAL EDUCATIONAL INSTITUTIONS IN YOGYAKARTA}

\begin{abstract}
This research aims to describe the importance of cultural-based education implementation analysis (Province Regulation no 5 Year 2011) in the Yogyakarta Special Province, especially in the Institute of courses and Trainings as a service for community education. This is a qualitative research. Results show that 1) cultural-based education socialization carried out structurally from province level to the Institute of Courses and Trainings through workshops, Training of Trainers, Conference, and Forum Group Discussions; 2) The readiness level of the Institute of Courses and Trainings in running cultural-based education are various in terms of content, process, facilities, and human resources. There are 46 accredited Institute of Courses and Trainings but, half of them does not apply cultural-based education; 3) Several identified difficulties on the Province Regulation no 5 Year 2011 implementation consist of problem complexity faced by the Institute of Courses and Trainings, difficulties in identifying indicators of cultural-based education based on the Yogyakarta cultural values so that is not easy to integrate with the subjects, longer time to arrange cultural-based curriculum toward new formats. It is caused by the changing of team members over time.
\end{abstract}

Keywords: Cultural-based education 


\section{PENDAHULUAN}

Pendidikan tidak mungkin bisa dipisahkan dari kebudayaan. Pada hakekatnya pendidikan adalah proses pembudayaan, dengan tujuan agar peserta didik kelak dapat hidup layak dan berguna bagi diri dan bagi kehidupan masyarakatnya, sehingga mesti berbasis budaya bangsanya. Pentingnya budaya sebagai basis pendidikan dinyatakan oleh Bruner (Zamroni, 2013:25) "culture shapes the mind... it provides us with the toolkit by which we construct not only our worlds but our very conception of ourselves and our powers".

Hal senada dinyatakan HAR Tilaar (2002:15); Vikas Gora (2011:24) bahwa pendidikan merupakan instrumen penting sebagai sebuah gerakan perubahan dengan menempatkan budaya pada tempat yang amat penting dalam proses transformasi pengetahuan, sikap dan kebiasaan-kebiasaan yang dimanifestasikan. Persoalannya adalah sistem pendidikan yang instan, terkesan berubah-ubah belum sepenuhnya menggunakan budaya sebagai landasan berpikir, berperilaku pendidikan. Salah satu fenomena yang dapat menjelaskan persoalan tersebut adalah banyaknya peristiwa pendidikan yang menyimpang seperti kekerasan pendidik terhadap peserta didik, banyaknya pelajar yang terlibat dengan obat-obat terlarang, tawuran dan sebagainya yang justru mencederai makna pendidikan itu.

Jika paradigma pendidikan bermuara pada pengembangan pendidikan berbasis sains, teknologi, ekonomi, etika dan estetika, maka saat ini paradigma sains, teknologi dan ekonomi cenderung dominan dibanding dua dimensi yang lain. Aspek estetika dan etika yang kurang memperoleh perhatian dalam proses pendidikan berdampak pada lingkungan alam, sosial yang kurang mampu mendukung proses pembentukan manusia untuk memiliki kesantunan, keadaban serta perilaku-perilaku humanis yang sesungguhnya sangat diperlukan bagi peradaban manusia pada abad
XXI ini. Perkembangan ilmu pengetahuan dan teknologi sangat erat kaitannya dengan kebutuhan manusia untuk memahami dan selalu berusaha menguasai alam agar supaya dapat memetik manfaat sebesar-besarnya atau mengurangi bahkan kalau mungkin mencegah kerugian yang ditimbulkan oleh alam. Dalam hal tertentu, teknologi demikian menubuhnya pada manusia, seperti telepon seluler atau iPad, orang merasa tidak lengkap kalau telepon genggam atau tabletnya tertinggal (Sumarno, 2013:6).

Perubahan yang serba cepat di era global dengan banyak tantangan memerlukan manusia yang tidak hanya dapat berpikir akan tetapi juga mampu melakukan pilihan-pilihan yang cerdas (Tilaar, 2002:65). Artinya bahwa segala ancaman internal maupun eksternal merupakan peluang untuk melakukan pembenahanpembenahan khususnya di bidang pendidikan agar secara sistem, program, proses dapat menghasilan kualitas pendidikan, kualitas manusia sebagaimana yang dirumuskan oleh sistem pendidikan nasional yakni manusia yang tangguh, berakhlak mulia dan memiliki peradaban, kesantunan sebagai individu bersama satuan sosialnya.

Nampaknya keprihatinan terhadap fenomena pemisahan pendidikan dan kebudayaan serta berbagai peristiwa pendidikan yang mencederai dunia pendidikan telah mendorong Gubernur DIY untuk mengeluarkan Peraturan Daerah Nomor 5 tahun 2011 tentang pengelolaan pendidikan berbasis budaya. Peraturan Gubernur DIY tersebut ditindaklanjuti oleh Dinas Pendidikan dan Olah Raga DIY melakukan perencanaan pengelolaan pendidikan dengan menyusun pedoman-pedoman yang menyangkut pentingnya pedoman pendidikan berbasis budaya. Panduan pendidikan berbasis budaya yang memuat standar isi kurikulum pendidikan berbasis budaya, standar pengelolaan pendidikan berbasis budaya, pengembangan bahan

Analisis Implementasi Pendidikan Berbasis Budaya pada Lembaga Pendidikan Non-Formal ... 
ajar, pengembangan silabus, pengembangan rencana pelaksanaan pembelajaran dan rincian materi pendidikan berbasis budaya disusun, disosialisasikan agar dapat diimplementasikan ke dalam pengelolaan pendidikan di semua jenis dan jenjang pendidikan yang ada di wilayah DIY.

Kebudayaan merupakan sesuatu yang dinamis dengan unsur-unsur seperti nilainilai luhur yang dipandang sebagai "blue print", cetak biru, sesuatu yang diyakini, dimiliki dan diakui bernilai oleh sebagian besar masyarakat. Selain nilai, kebudayaan juga memiliki unsur wujud perilaku (aktivitas) atas nilai tersebut, kebudayaan juga memiliki artefak (wujud, material, sebagai hasil aktivitas bersama, berpola atau ada nilai keajegan). Secara umum nilai luhur, artefak dan adat, memiliki tujuan yang cukup kompleks yakni mengenal, apresiasi, internalisasi dan kreatif dengan masing-masing institusi pendidikan. Untuk mengenal nilai, artefak dan adat dapat dilakukan dengan berbagai kegiatan yang bersifat monolitik, integratif tematik, ekstra kurikuler dan budaya satuan pendidikan sesuai dengan semua jenjang dan jenis pendidikan.

Konsep di atas menunjukkan bahwa proses pembelajaran tidak cukup hanya untuk meningkatkan pengetahuan (melalui core subjects) saja, harus dilengkapi dengan berkemampuan kreatif-kritis, berkarakter kuat (bertanggung jawab, sosial, toleran, produktif, adaptif). Di samping itu juga didukung dengan kemampuan memanfaatkan informasi dan berkomunikasi. Dengan demikian keistimewaan DIY harus mampu dikaitkan dengan keistimewaan pendidikan. "Nilai-nilai adiluhung Yogyakarta harus bisa diterapkan dalam pengelolaan dan penyelenggaraan pendidikan sehingga akan memperkuat jati diri dan karakter siswa" .

Sebagai sumber daya, modal sosial ini memberi kekuatan atau daya dalam beberapa kondisi-kondisi sosial dalam masyarakat. Sebenarnya dalam kehidupan manusia dikenal beberapa jenis modal, yaitu natural capital, human capital, physical capital dan financial capital. Modal sosial akan dapat mendorong keempat modal di atas dapat digunakan lebih optimal lagi. Secara substansial, "modal manusia" (human capital) memiliki kandungan lain selain pengetahuan dan keterampilan, yaitu kemampuan masyarakat untuk melakukan asosiasi (berhubungan) satu sama lain. Modal yang demikian ini disebut dengan "modal sosial" (social capital), yaitu kemampuan masyarakat untuk bekerja bersama demi mencapai tujuan bersama dalam suatu kelompok dan organisasi (Coleman, 1988:90).

Tantangan bagi dunia pendidikan umumnya dan pendidikan non formal dan informal adalah bagaimana hasil pendidikan tidak sekedar menekankan pada penguatan modal manusia (pengetahuan dan keterampilan) tapi juga mengarahkan pada optimalisasi potensi masyakat yang tertuang dalam modal sosial dengan menggunakan 18 nilai adiluhung seperti kejujuran, kerendahan hati; ketertiban/ kedisiplinan; kesusilaan; kesopanan/kesantunan; kesabaran; kerjasama; toleransi; tanggung jawab; keadilan; kepedulian; percaya diri; pengendalian diri; integritas; kerja keras/keuletan/ketekunan; ketelitian; kepemimpinan; dan/atau ketangguhan (tercantum dalam Perda Propinsi DIY nomor 5 tahun 2011, pasal 3).

Berdasarkan argumentasi sebagaimana dijelaskan pada bagian di atas, penelitian ini hendak mempertanyakan bagaimana kebijakan publik tentang pengelolaan pendidikan berbasis budaya di Yogyakarta dapat diterapkan di sekolah-sekolah formal, nonformal di semua jenis dan jenjang. Oleh karena berbagai pertimbangan dan keterbatasan kemampuan, fokus penelitian ini diarahkan pada analisis sosialisasi, kesiapan dan bentuk kesulitan lembaga kursus dan pelatihan kaitannya dengan implementasi pengelolaan pendidikan berbasis budaya. 


\section{METODE}

Pendekatan yang digunakan dalam penelitian ini adalah kualitatif dengan tipe deskriptif eksploratif. Kajian fenomena pendidikan dengan pendekatan kualitatif ini dapat digunakan untuk menganalisis hubungan antar aspek agar secara holistik dapat ditemukan kecenderungan pola dan temanya untuk diintepretasikan dan dimaknai. Permasalahan implementasi pendidikan berbasis budaya bukan hanya persoalan bagaimana dimensi nilai budaya diterapkan, akan tetapi lebih pada bagaimana nilai budaya yang secara hakiki terdapat dalam kehidupan masyarakat menjadi bermakna dalam setiap perilaku individu khususnya pelaku pendidikan pada LKP.

Penelitian ini difokuskan pada analisis deskriptif secara mendalam khususnya aspek sosialisasi, kesiapan dan kesulitan implementasi pendidikan berbasia budaya di LKP yang terdaftar dalam direktori dinas pendidikan propinsi DIY. Data yang berkaitan dengan aspek sosialisasi pendidikan berbasis budaya meliputi dokumen, aktivitas yang dilakukan serta pihak-pihak yang terlibat dalam proses sosialisasi tersebut. Sementara itu kesiapan LKP dalam upaya mengimplementasikan pendidikan berbasis budaya meliputi dokumen isi kurikulum, proses, sarana prasarana, aktivitas pengembangan sumber daya manusia berkaitan dengan rancangan implementasi pendidikan berbasis budaya.

Dalam melakukan analisis implementasi pendidikan berbasis budaya, penelitian ini dilakukan di LKP-LKP yang diprediksi dalam proses menerapkan pembelajarannya berbasis budaya secara isi, proses, sarana prasaran serta aktivitas pendukung lain yang dianggap dapat memperkuat setiap aspek yang dianalisis. Lokasi penelitian ditentukan berdasarkan rekomendasi dinas pendidikan bagian perencanaan dan diperkuat oleh ketua forum LKP yang memiliki pemahaman tentang kondisi di lapangan. Secara metodologis penentuan LKP di DIY sebagai sampel penelitian ditetapkan dengan menggunakan sistem purposif random sampling yaitu dipilih berdasarkan kriteri-kriteria tertentu. Kriteria tersebut adalah LKP yang sudah terakreditasi BANPNF, LKP yang melayani kebutuhan belajar dengan muatan budaya atau LKP yang sudah siap menerapkan pendidikan berbasis budaya.

Jenis data yang diperlukan dalam penelitian ini adalah data primer dan data sekunder. Data primer meliputi informasi yang relevan dengan aspek-aspek yang diteliti dilakukan dengan metode observasi dan wawancara secara mendalam kepada sumber data yang terkait dengan aspek-aspek tersebut. FGD juga dilakukan sebagai teknik yang dapat meningkatkan efektivitas dan efisiensi penelitian terutama pada penggalian data yang memerlukan klarifikasi/verfikasi data secara bersama-sama. Sementara itu data sekunder dikumpulkan dengan menggunakan studi dokumentasi yang berkaitan dengan implementasi pendidikan berbasis budaya, meliputi peraturan pemerintah daerah, seperangkat alat pendidikan seperti kurikulum, rancangan pembelajaran. Teknik obeservasi untuk melengkapi field research yang dilakukan ketika penelitian ini melihat secara langsung proses implementasi pendidikan berbasis budaya dilakukan LKP yang dianggap memiliki kualitas proses layanan pendidikan yang baik bagi stakeholder.

Dari sekitar 137 LKP yang ada di DIY, terdapat 46 LKP yang memiliki kelayakan sesuai kriteria untuk digunakan sebagai sampelnya. Oleh karena rumpun keterampilan dari 46 LKP memiliki kesamaankesamaan maka hanya diambil 2 rumpun jenis keterampilan yaitu 1) rumpun keterampilan budaya seperti tata kecantikan rambut, hantaran dan batik; 2) rumpun LKP dengan jenis keterampilan kursus komputer, montir dan servis hp. Berdasarkan rumpun keterampilan itulah peneli-

Analisis Implementasi Pendidikan Berbasis Budaya pada Lembaga Pendidikan Non-Formal ... 
tian menetapkan 6 LKP sebagai sumber data atau sebanyak 12 ketua dari kedua rumpun keterampilan. Salah satu alasan adalah kedua rumpun yang berbeda inipun memiliki hak dan kesempatan yang sama dalam membangun kepribadian pendidik dan peserta didik untuk menanamkan nilai-nilai luhur budaya yang sejak lama telah dimiliki oleh Daerah Istimewa Yogyakarta.

Analisis model interaktif ini menuntut setiap data atau informasi yang terkumpul diklasifikasi untuk dianalisis dalam kaitannya dengan aspek-aspek yang diteliti. Data yang terkumpul selanjutnya direduksi, dirangkum, dipilih hal-hal yang pokok agar dapat ditemukan pola hubungan antar aspeknya. Seluruh data yang sudah direduksi selanjutnya dilakukan display data agar memudahkan peneliti melihat gambaran fenomena.

\section{HASIL DAN PEMBAHASAN}

Daerah Istimewa Yogyakarta merupakan daerah yang memiliki keragaman budaya, karakteristik dan keunikan yang tidak dimiliki daerah lain. Keragaman tersebut dapat ditinjau dari sisi geografis, potensi sumber daya, ketersediaan sarana dan prasarana, latar belakang dan kondisi sosial budaya, dan berbagai keragaman lainnya yang terdapat di setiap daerah kabupaten/kota di Daerah Istimewa Yogyakarta. Keragaman tersebut melahirkan tingkatan kebutuhan dan tantangan pengembangan yang berbeda dalam rangka meningkatkan pelestarian budaya, mutu pendidikan, pemerataan pendidikan dan mencerdaskan kehidupan masyarakat di setiap daerah kabupaten/kota di Daerah Istimewa Yogyakarta

Lembaga Kursus dan Pelatihan yang berkembang di Yogyakarta untuk melayani kebutuhan pendidikan nonformal termasuk salah satu lembaga pendidikan yang juga mengemban amanat diberlakukannya pengelolaan pendidikan berbasis budaya. Secara konsep Lembaga Kursus dan Pelatihan dengan heterogenitas stakeholder memiliki nilai strategis untuk mengembangkan serta mentransfer nilai-nilai luhur budaya melalui proses penyelenggaraan pendidikan. Pemerintah Provinsi Daerah Istimewa Yogyakarta melalui peraturan daerah Provinsi Daerah Istimewa Yogyakarta nomor 5 tahun 2011 tentang pengelolaan pendidikan berbasis budaya, memandang perlu sosialisasi dan pengembangan muatan nilai budaya ke dalam proses pembelajaran secara terintegrasi. Persoalannya adalah sampai seberapa jauh kesiapan LKP dalam menerapkan pendidikan berbasis budaya. Untuk menjawab hal tersebut diperlukan analisis terhadap aspek-aspek yang berkaitan dengan pendidikan berbasis budaya. Oleh sebab itu secara berturut-turut akan dijelaskan hasil analisis aspek sosialisasi, kesiapan dan kesulitan-kesulitan LKP dalam menerapkan dan mengembangkan pendidikan berbasis budaya.

\section{Sosialisasi Pengelolaan Pendidikan Ber- basis Budaya}

Sebuah program pengelolaan pendidikan berbasis budaya yang dituangkan dalam bentuk kebijakan publik memiliki implikasi yang begitu luas pada aspek perencanaan, sosialisasi, pengelolaan, pelaksanaan hingga evaluasi. Kegiatan sosialisasi dalam perencanaan pendidikan ini sangat penting untuk terwujudnya kualitas pendidikan berdasarkan standar yang ada. Pengelolaan pendidikan berbasis budaya yang dikembangkan atas dasar Perda Propinsi DIY meliputi banyak komponen pendidikan dalam konteks sinergitas multi sektoral yang meliputi:

1. Pemerintah daerah, dinas pendidikan dan olah raga propinsi DIY dengan dewan pendidikan yang merancang konsep pendidikan berbasis budaya,

2. Pelaku pendidikan yang meliputi kepala sekolah, ketua LKP, guru, tutor, praktisi dan tokoh masyarakat termasuk akademisi perguruan tinggi, 
3. Nara sumber yang membidangi perencanaan pendidikan khususnya dalam konteks pendidikan berbasis budaya. Secara sistematis, terstruktur, sosialisasi pengelolaan pendidikan berbasis budaya dilakukan dengan menghadirkan nara sumber serta pelaku pendidikan terkait. Sosialisasi pengelolaan pendidikan berbasis budaya ini telah dilakukan beberapa kali dalam tahun 2013 yang lalu agar Lembaga layanan pendidikan masyarakat seperti LKP menindaklanjuti dengan menyusun sejumlah panduan standar mutu pendidikan beserta indikator-indikatornya. Dalam kurun waktu 3 hingga 5 bulan setiap lembaga pendidikan di semua jenis dan jenjang diberi kesempatan untuk menyusun panduan standar isi kurikulum, standar pengelolaan pendidikan berbasis budaya, pengembangan bahan ajar, pengembangan silabus, pengembangan RPP dan rincian materi pendidikan berbasis budaya. Prinsip penyusunan standar di semua lembaga pendidikan formal maupun nonformal adalah sama yaitu keterbukaan, terintegrasi dengan materi pembelajaran, serta mengutamakan nilainilai luhur budaya Yogyakarta.

Dari hasil wawancara prinsip penyusunan dengan melibatkan pihak-pihak yang berkepentingan dengan layanan pendidikan ini dilakukan eksplorasi unsur-unsur budaya khas Yogyakarta sebagai muatan materi kurikulum. Dalam implementasinya, unsur-unsur yang digali dari nilai budaya Yogyakarta terdapat desentralisasi yaitu pengembangan isi kurikulum, proses, sarana dan prasarana disesuaikan dengan kondisi dan karakteristik daerah masing-masing. Konsep implementasi pendidikan berbasis budaya tersebut sangat relevan dengan prinsip pendidikan yang berasaskan demokrasi, prinsip pemberian kebebasan bagi lembaga secara bertanggungjawab. Rancangan pendidikan berbasis budaya dengan merevitalisasi unsur-unsur budaya khas Yogyakarta tersebut dapat diimplementa- sikan secara kontekstual sesuai kebutuhan daerah, satuan pendidikan dan peserta didik.

Sosialisasi yang dilakukan di tingkat dinas pendidikan, para ketua lembaga pendidikan memiliki kewajiban untuk melakukan sosialisasi yang sama ke setiap lembaga pendidikan lain dalam satu rayon. Pola sosialisasi dilakukan dengan seminar, workshop selama beberapa kali, per tahap, per target setiap produk yang dihasilkan untuk direview, direvisi, disahkan dan diinstitusionalisasikan secara keseluruhan kepada semua sekolah, lembaga pendidikan nonformal pada jenis dan jenjang. Secara detail, unsur-unsur budaya khas Yogyakarta dapat dilihat pada tabel 1 .

Analisis Kesiapan LKP dalam Implementasi Pendidikan Berbasis Budaya

Analisis kesiapan yang meliputi isi kurikulum, proses, sarana prasarana dan sumber daya manusia yang dimiliki LKP:

Isi kurikulum pendidikan berbasis budaya yang dikembangkan oleh lembaga kursus dan pelatihan menyangkut organisasi materi sesuai dengan bidang ilmunya. Pemetaan kompetensi merupakan strategi awal dilakukannya standarisasi isi. Secara garis besar standar isi kurikulum dapat dilihat dalam strategi pembelajaran sebagaimana dilihat pada pada gambar 1 .

Alur pelaksanaan pembelajaran yang diterapkan memiliki implikasi terhadap tingkat kesiapan dalam rancangan pembelajaran dalam bidang materi masingmasing. Alur pelaksanaan pembelajaran tersebut mengisyaratkan bahwa stetiap materi yang dipersiapkan idealnya diorganisasi. Di 12 LKP dengan rumpun keilmuan yang berbeda-beda masih dalam proses penyempurnaan terutama untuk muatan budaya yang diberlakukan. Meskipun materi pembelajaran yang dilengkapi dengan perangkat yang lain seperti modul, RPP maupun silabus yang

Analisis Implementasi Pendidikan Berbasis Budaya pada Lembaga Pendidikan Non-Formal ... 
Tabel 1. Unsur-unsur Budaya Khas Yogyakarta sebagai Muatan Materi Kurikulum

\begin{tabular}{|c|c|c|}
\hline No. & $\begin{array}{c}\text { Unsur-unsur budaya khas } \\
\text { Yogyakarta }\end{array}$ & Muatan Materi, antara lain: \\
\hline 1. & Nilai-nilai luhur: & \\
\hline & Spiritual & $\begin{array}{l}\text { Kejujuran } \\
\text { Kesusilaan } \\
\text { Kesabaran } \\
\end{array}$ \\
\hline & Personal - moral & $\begin{array}{l}\text { Kerendahan hati } \\
\text { Tanggung jawab } \\
\text { Percaya diri } \\
\text { Pengendalian diri } \\
\text { Integritas } \\
\text { Kepemimpinan } \\
\text { Ketelitian } \\
\text { Ketangguhan } \\
\text { Welas asih } \\
\end{array}$ \\
\hline & Sosial & $\begin{array}{l}\text { Kerja sama } \\
\text { Keadilan } \\
\text { Kepedulian } \\
\end{array}$ \\
\hline & Nasionalisme & $\begin{array}{l}\text { Ketertiban/kedisiplinan } \\
\text { Kesopanan/kesantunan } \\
\text { Toleransi } \\
\text { Kerja keras/ketekunan/keuletan }\end{array}$ \\
\hline 2. & Artefak & \\
\hline & Sastra & $\begin{array}{l}\text { Tembang } \\
\text { Geguritan } \\
\text { Cerita rakyat }\end{array}$ \\
\hline & Pertunjukan; tari, gamelan, gending & $\begin{array}{l}\text { Seni tari } \\
\text { Gending } \\
\text { Teater tradisional } \\
\text { Wayang } \\
\text { Dolanan anak }\end{array}$ \\
\hline & Lukis & Model lukisan batik \\
\hline & Busana & $\begin{array}{l}\text { Batik corak Yogyakarta } \\
\text { Busana adat } \\
\text { Surjan (taqwa) } \\
\text { Dodot }\end{array}$ \\
\hline & Kriya & $\begin{array}{l}\text { Gerabah } \\
\text { Keris } \\
\text { Kerajinan } \\
\text { ukiran }\end{array}$ \\
\hline & Arsitektur & $\begin{array}{l}\text { Rumah adat } \\
\text { Bangunan cagar budaya } \\
\text { Candi } \\
\text { Benteng } \\
\text { Gapura } \\
\text { Tugu }\end{array}$ \\
\hline & Boga & Makanan khas \\
\hline 3. & Adat & \\
\hline & Sosial - jati diri & Gotong royong, upacara tradisional, nyadran \\
\hline & Ekonomi - welfare & Sistem lumbung desa, pasaran \\
\hline & Politik - kekuasaan & Sekaten, merti dusun, bekakak, jumenengan \\
\hline
\end{tabular}


digunakan selama ini belum diorganisasi dengan format sesuai dengan pedoman, akan tetapi secara substansi, sistematika berpikir dan strategi atau langkah-langkah pembelajaran sudah terdokumentasi.

Unsur-unsur budaya yang dimasukkan dalam standar isi memiliki penekanan yang berbeda-beda, misalnya untuk pembelajaran keterampilan membatik, tata kecantikan rambut secara isi sudah memuat unsur budaya, namun untuk prioritas nilai budaya menjadi berbeda. Ketika materi keterampilan membatik, nilai adiluhung Yogyakarta yang diperkenalkan adalah corak-corak yang menggambarkan nilai ketekunan, keagungan, dengan proses membatik yang mengutamakan kesabaran, menghargai hasil karya nenek moyang. Sementara itu pada keterampilan komputer juga menekankan makna kesabaran misalnya ketika pembelajaran menghendaki secara bersama kelompok peserta didik untuk melakukan aktivitas yang sama dengan materi yang sama, namun ternyata ada beberapa peserta didik menggunakan waktu yang bersama itu untuk aktivitas dengan materi yang lain, maka peserta didik ini dinilai sebagai belum memiliki tingkat kesabaran sesuai standar. Disadari oleh sebagian LKP bahwa tidak semua materi pembelajaran harus diberi muatan nilai budaya yang sama. Hanya pada materi-materi pembelajaran yang memiliki nilai strategis saja yang harus diberi muatan budaya.

Seluruh LKP yang diobservasi dalam proses pembelajaran menggunakan sarana prasarana sebagai penunjang pendidikan, namun pada keterampilan-keterampilan tertentu sarana prasarana yang tersedia masih minimalis, misalnya untuk praktek potong rambut, peralatan yang digunakan tidak selengkap yang dibutuhkan. Akan tetapi nilai-nilai budaya yang terintegrasi ke dalam proses pembelajaran adalah sikap melayani secara santun dalam tutur kata dan bahasa, demikian pula pada keterampilan montir, sikap yang santun sangat ditekankan dalam setiap proses pembelajaran. Contoh pengintegrasian dilakukan melalui pembelajaran kepribadian dan lain-lainnya yang dipandang sesuai.

Identifikasi nilai-nilai budaya dilakukan untuk menyamakan persepsi mengenai diskripsi niai-nilai budaya tersebut. Berikut diskripsi tentang nilai-nilai budaya yang akan diintegrasikan:

Identifikasi kesulitan dalam menerapkan pendidikan berbasis budaya

Berdasarkan hasil wawancara mendalam mengenai kesulitan-kesulitan yang dihadapi LKP pada saat persiapan implementasi pendidikan berbasis budaya dapat diidentifikasi:

1. Sejak diterbitkan Perda tentang pengelolaan penddikan berbasis budaya pertengahan tahun 2013 hingga akhir tahun 2013 seminar, workshop secara berulang kali, salah satu kegiatan revitalisasi/eksplorasi unsur budaya Yogyakarta dengan menemukan indikator nilai dirasakan sangat rumit dan tidak mudah untuk diintegrasikan ke dalam materi pembelajaran. Hal ini karena begitu banyak nilai-nilai adiluhung budaya Yogyakarta sementara kompleksitas permasalahan LKP pun juga sangat banyak.

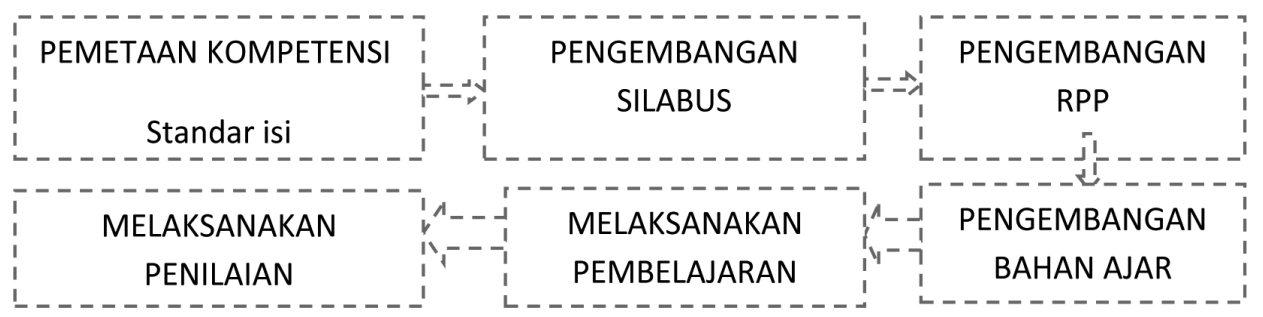

Gambar 1. Standar Isi Kurikulum dalam Strategi Pembelajaran

Analisis Implementasi Pendidikan Berbasis Budaya pada Lembaga Pendidikan Non-Formal ... 
Tabel 2. Diskripsi Nilai-nilai Budaya

\begin{tabular}{|c|c|}
\hline Nilai & Diskripsi \\
\hline Religio-spiritual & $\begin{array}{l}\text { Rela hati lahir batin (lila legawa lair trusing batin) bersungguh-sungguh berusaha } \\
\text { keras secara terus-menerus sepi ing pamrih ramé ing gawé) mengusahakan dan } \\
\text { menjaga kebenaran (bener), kebaikan (becik), keindahan (hayu), keselamatan dan } \\
\text { kelestarian (rahayu) dunia (hamemayuhayuning bawana). } \\
\text { Ikhlas (lila legawa) dan dengan sabar menerima (sabar narima) peran dan nasib } \\
\text { perjalanan hidupnya. Kematian, jodoh, anugerah, garis nasib, dan rejeki bagi tiap- } \\
\text { tiap orang merupakan kepastian yang telah ditentukan oleh Tuhan (siji pesthi, loro } \\
\text { jodho, telu wahyu, papat kodrat, lima bandha). }\end{array}$ \\
\hline Moral & $\begin{array}{l}\text { Menjaga kebaikan, keindahan, dan kelestarian dunia harus dimulai dari diri } \\
\text { manusia sendiri dengan menjaga kebenaran pemikiran dan ucapan, kebaikan } \\
\text { perilaku, keharmonisan dan keindahan tatanan pergaulan hidup, baik dengan } \\
\text { sesama manusia, dengan alam semesta. } \\
\text { Tidak mudah takjub dengan kesementaraan perubahan yang memukau (aja } \\
\text { gumunan, aja kagetan), dan jangan pula menyombongkan diri dan meremehkan } \\
\text { orang lain dikala dirinya berjaya sementara orang lain sedang sengsara (aja dumeh). } \\
\text { Senantiasa berusaha menanam kebajikan dan terus-menerus menyemai budi luhur } \\
\text { sebagai keutamaan (nandur kabecikan, ndhedher kautaman). } \\
\text { Menyenangkan hati orang lain (amemangun karyénak tyasing sesama), seperti } \\
\text { mengemukakan pendirian secara lembut (pambegané alus; landhep tanpa natoni), } \\
\text { berhati-hati dalam berbicara (yènangucap ngarah-arah). } \\
\text { Tingkah dan tutur katanya bersahaja (tingkah una-uninéprasaja). } \\
\text { Setiap ucapannya terasa sejuk menembus kalbu karena dilandasi nurani yang bersih } \\
\text { (saujaré manis trus ati), bertenggang rasa dan berbelas kasih kepada semua makhluk } \\
\text { hidup. }\end{array}$ \\
\hline Kemasyarakatan & $\begin{array}{l}\text { Hidup berlandaskan kasih sayang dengan mewujudkan dan senantiasa menjaga } \\
\text { kerukunan. } \\
\text { Saling asah asih asuh. } \\
\text { Adanya solidaritas atau kesetiakawanan sosial. }\end{array}$ \\
\hline Adat dan tradisi & $\begin{array}{l}\text { Memelihara setiap acara adat karena terdapat nilai-nilai kebijaksanaan hidup yang } \\
\text { dikandung dan dipesankannya. }\end{array}$ \\
\hline $\begin{array}{l}\text { Pendidikan dan } \\
\text { pengetahuan }\end{array}$ & $\begin{array}{l}\text { Menumbuhkan, mengelola, dan meningkatkan kualitas kecerdasan kehidupannya, } \\
\text { baik kecerdasan kejiwaan yang meliputi religio-spiritualitas (takwa), moralitas } \\
\text { (karsa), emosionalitas (rasa), dan intelektualitasnya (cipta), maupun kesehatan dan } \\
\text { pengembangan raganya. Oleh karena itu, kepada peserta didik bukan hanya } \\
\text { dibekali ilmu pengetahuan, teknologi, dan ketrampilan teknis suatu pekerjaan, } \\
\text { melainkan harus ditanamkan nilai-nilai. }\end{array}$ \\
\hline Teknologi & $\begin{array}{l}\text { Teknologi menjadikan kemudahan, kenikmatan, dan } \\
\text { kenyamanan hidup. }\end{array}$ \\
\hline $\begin{array}{l}\text { Penataan ruang dan } \\
\text { arsitektur }\end{array}$ & $\begin{array}{l}\text { Mengingatkan manusia agar senantiasa sadar diri (éling) tentang asal-muasal } \\
\text { kehidupannya dan tempat kembalinya kelak (Sang Khalik). } \\
\text { Tata rakit keruangan harus memungkinkan tumbuh dan berkembangnya } \\
\text { spiritualitas manusia secara wajar. } \\
\text { Terlaksananya hubungan antarmanusia secara wajar dan harmonis. } \\
\text { Hubungan yang sinergis-harmonis antara manusia dan alam. }\end{array}$ \\
\hline Mata pencaharian & $\begin{array}{l}\text { Bersungguh-sungguh berusaha keras secara terus-menerus (sepi ing pamrih ramé ing } \\
\text { gawé). } \\
\text { Mengusahakan dan menjaga kebenaran, kebaikan, keindahan, keselamatan, dan } \\
\text { kelestarian dunia (hamemayu hayuning bawana). }\end{array}$ \\
\hline Nilai kesenian & $\begin{array}{l}\text { Berkomunikasi spiritual manusia dengan Tuhan. } \\
\text { Berkomunikasi sosial manusia dengan sesama manusia. } \\
\text { Berkomunikasi natural manusia dengan seluruh penghuni alam semesta. } \\
\text { Menjadikan sarana hiburan dan sekaligus media edukasi (tontonan lan tuntunan). }\end{array}$ \\
\hline
\end{tabular}




\begin{tabular}{|c|c|}
\hline Bahasa & $\begin{array}{l}\text { Berbahasa sesuai perspektif waktu, tempat, dan konteks (empan papan duga prayoga). } \\
\text { Menjaga, melestarikan, dan mengembangkan bahasa Jawa, baik dalam bentuk } \\
\text { tuturan maupun tulisan, di dalam pergaulan hidup yang wajar. }\end{array}$ \\
\hline $\begin{array}{l}\text { Benda cagar budaya } \\
\text { dan kawasan cagar } \\
\text { budaya }\end{array}$ & $\begin{array}{l}\text { Berusaha keras agar setiap benda budaya bersejarah dan kawasan situs yang } \\
\text { melingkupinya senantiasa dijaga, dilestarikan, dan dilindungi sebagai benda cagar } \\
\text { budaya dan kawasan cagar budaya. }\end{array}$ \\
\hline $\begin{array}{l}\text { Nilai kepemimpinan } \\
\text { dan pemerintahan }\end{array}$ & $\begin{array}{l}\text { Tampil di depan memberi teladan bagi yang dipimpin (ing ngarsa sung tuladha). } \\
\text { Memotivasi yang dipimpin (ing madya mangun karsa). } \\
\text { Memberi dorongan, kekuatan, dan perlindungan (ing wuntat tut wuri handayani). }\end{array}$ \\
\hline $\begin{array}{l}\text { Kejuangan dan } \\
\text { kebangsaan }\end{array}$ & $\begin{array}{l}\text { Perasaan memiliki negara ini (duwérasa handarbèni), } \\
\text { berjuang sampai titik darah penghabisan (wani mèlu hangrungkebi). } \\
\text { Mawas diri dan berusaha keras memberi kontribusi kepada masyarakat, bangsa, } \\
\text { dan negara (mulat salira hangrasa wani). }\end{array}$ \\
\hline $\begin{array}{l}\text { Semangat } \\
\text { keyogyakartaan }\end{array}$ & $\begin{array}{l}\text { Percaya diri dalam bertindak (sengguh). } \\
\text { Tidak akan mundur setapak pun (konsisten). } \\
\text { Siap menanggung segala risiko apa pun (konsekuen) yang harus dihadapi (ora } \\
\text { mingkuh) dengan penuh rasa tanggung jawab (lamunkapéngkoking pancabaya ubayané } \\
\text { datan mbalénjani). }\end{array}$ \\
\hline
\end{tabular}

2. Banyaknya perbedaan penafsiran di antara ketua LKP tentang nilai budaya Yogyakarta untuk dideskripsikan agar mudah dipahami orang lain sehingga pendeskripsian makna nilai budaya Yogyakarta menjadi terinci namun memakan waktu yang lama, meskipun dalam rumpun materi pembelajaran yang relatif sama.

3. Pemetaan kompetensi standar isi (kurikulum), pengembangan silabus, RPP, bahan ajar dan perangkat pendukung pendidikan lain yang dilakukan secara kolektif antar LKP yang berbeda-beda jenis dan jenjang keterampilannya bukanlah sebuah kegiatan yang mudah dilakukan. Salah satu penyebabnya adalah personil yang terlibat pada awal-awal pemetaan tidak sama, sehingga tertunda, membutuhkan waktu yang lama dan melelahkan banyak pihak.

\section{PENUTUP \\ Simpulan}

Pengelolaan pendidikan berbasis budaya yang diatur dalam peraturan daerah di DIY dapat dimaknai sebagai sebuah kebijakan publik oleh karena menyangkut kepentingan banyak pihak. Oleh karena orientasi pengelolaan pendidikan yang berbasis budaya ini sebenarnya bukanlah hal baru bagi dunia pendidikan, maka analisis terhadap aspek sosialisai, kesiapan perangkat pendukung pendidikan serta analisi kesulitan LKP dalam implementasi pendidikan berbasis budaya menjadi penting dan relevan untuk dieksplor sebagai kajian yang bermakna bagi kepentingan pembangunan pendidikan.

Analisis terhadap pengintegrasian nilai budaya ke dalam materi-materi pembelajaran meliputi standar isi kurikulum, pengembangan silabus, pengembangan bahan ajar, pelaksanaan pembelajaran hingga evaluasinya pada prinsipnya merupakan sebuah pembudayaan. Menanamkan nilai-nilai luhur Yogyakarta di beberapa LKP menjadi menarik untuk dikembangkan oleh karena dalam penerapannya pendidikan berbasis budaya belum dapat diterapkan secara konsekuen.

\section{Saran}

Supaya program pengelolaan pendidikan berbasis budaya di setiap lembaga kursus dan pelatihan dapat diterapkan maka sharing muatan nilai budaya Yogyakarta diantara LKP yang serumpun maupun tidak serumpun dapat direalisasikan melalui kegiatan pengembangan persamaan persepsi yang dilakukan secara 
terstruktur. Kegiatan kolektif tersebut dapat membantu pihak-pihak yang terlibat dalam penyusunan kebijakan membuat revisi atau perbaikan-perbaikan yang disesuaikan dengan kondisi masyarakat yang heterogen.

\section{DAFTAR PUSTAKA}

Coleman, James S. (1988). Social Capital in the Creation of Human Capital The American Journal of Sociology, Vol. 94, p. 88-93.

Propinsi DIY. (2011). Peraturan Daerah Propinsi Daerah Istimewa Yogyakarta Nomor 5 Tahun 2011 Tentang Pengelolaan Dan Penyelenggaraan Pendidikan Berbasis Budaya. Yogyakarta: Pemerintah Daerah Istimewa Yogyakarta.
Sumarno. (2013). Pendidikan untuk Pencerahan dan Kemandirian Bangsa yang disampaikan pada Orasi Ilmiah dalam Rangka Dies Universitas Negeri Yogyakarta yang ke 49. Yogyakarta: Universitas Negeri Yogyakarta.

Tilaar, H.A.R. (2002). Pendidikan, Kebudayaan, dan Masyarakat Madani Indonesia. Bandung: Remaja Rosdakarya.

Vikas Gora. (2011). Humanist Education in Developing Countries. Rotterdam: Sense Publishers.

Zamroni. (2013). Pendidikan Populis Berbasis Budaya yang disampaikan pada Orasi Ilmiah dalam Rangka Dies Universitas Negeri Yogyakarta yang ke 49. Yogyakarta: Universitas Negeri Yogyakarta. 